Róbert Barta

\title{
A Historian in the Service of the Foreign Office
}

\author{
C. A. Macartney (1895-1978) and his writings on Hungary ${ }^{1}$
}

\begin{abstract}
This study is focusing on the life of C.A. Macartney as a diplomat and a historian especially on his writings on Hungary and the Hungarian history. The importance of this point goes back to the fact that he published a good number of books and articles on Hungary between the period of 1926 and 1978. It has been proved that this very rich publication activity of him basically influenced the attitudes of the English-speaking intellectual world towards Hungary and the Hungarians. In the life of Macartney the career as a diplomat and his so-called graphomaniac historian activity were closely connected. Although he was an expert of modern Hungarian history and worked for the British Foreign Office as a member of the Foreign Office Research Department (FORD) during WWII years, he also had a very well-grounded knowledge on the history of Austria and the Habsburg Empire. With his diplomatic activity and historical skill Macartney inspired generations of English-speaking historians, intellectuals and decision-makers in the subject of Hungary and the Hungarians. This fact well indicates the long-term importance and influence of C. A. Macartney as a pro-Hungarian historian and diplomat.

Keywords: C. A. Macartney, Foreign Office, British Historians on Hungary, Horthy regime
\end{abstract}

\section{Introduction}

The name of Carlile Aylmer Macartney is mostly known, in the Hungarian and international community of historians, due to his active political, diplomatic and propagandistic "lobby" activity in favour of Hungary between 1938 and 1945. Similarly, his books that were used in British and American universities for decades, made him well known. ${ }^{2}$ Profes- 
sionals, dealing with the modern British-Hungarian diplomatic relations and political history, have already touched upon various aspects of the work of the Scottish-Irish originated historian ${ }^{3}$ and his connection to Hungary. Nevertheless, no Hungarian, comprehensive and scholarly biography was created about "Macartney Elemér". ${ }^{4}$ Primarily, this paper wishes to introduce the work of Macartney as a Foreign Office employee and a historian, with a special focus on writings in connection with Hungary. The relevance of the above-mentioned is that Macartney published continuously from 1926 to $1978 .^{5}$ Many of his works written as an expert were published in several editions, provably influencing the contemporary opinion about Hungary among countries and people reading them in English. In this regard, the relation between Gyula Szekfü ${ }^{6}$ and Macartney should be examined, since the two careers intertwined multiple times while Macartney's perspective as a historian was significantly influenced by the work of the Hungarian historian. ${ }^{7}$

\section{Macartney: the historian and a diplomat}

During the career of the continuously publishing Macartney - who in this regard can be called graphomaniac - the historic, diplomatic and public functions were tightly linked. Between 1921 and 1925, he started off as a British vice-consul ${ }^{8}$ in Vienna, and during this time he had already been to Hungary many times, firstly, around Pécs, Baranya as a guest of university professor Sándor Krisztics, and the Hungarian National Association. ${ }^{9}$ During his years in Vienna he managed to build a friendship with Iván Hindy, the military attaché of the Hungarian embassy, who was the commander of Budapest as a general at the end of 1944. Macartney dedicated ${ }^{10}$ his most well-known work - October Fifteenth - to Hindy, who was sentenced to death by the people's court in 1946. Because of this, Macartney is still often put in a radical political context. As an employee of the Encyclopaedia Britannica - between 1926 and 1928 -, the League of Nations Union and the Intelligence Department of the League of Nations - between 1928 and 1934 - he extensively published works, popularizing the League of Nations. ${ }^{11}$ Due to this extensive amount of published material, many publications in connection with Hungary resulted. ${ }^{12}$ From these writings we may conclude that Macartney had a strong social sense. His liberal position and reform thinking appear in some of his later writings about Hungary. In this context, Macartney 
repeatedly judged the Horthy system due to the lack of the land reform and the inadequate social policy. At the same time, the critics of Macartney highlight that the British historian-diplomat was too proHungarian in his works, depicting a relatively positive picture about the Horthy regime, because of which he got close to the historic practice represented by Gyula Szekfü. His relationship with Gyula Szekfü started in the beginning of the 1920's in Vienna, where Szekfü as the staff member of the former Austro-Hungarian archive - by this time he was the commissioner of the disposal from the Hungarian side - introduced him the ways of studying Hungarian historical sources. ${ }^{13}$ In the 1920 's both of them were writing entries for The Encyclopaedia Britannica and were in correspondence. During the spring of 1929, Macartney was asked by Szekfü to accept the leadership of the Hungarian department to be founded at the University of London, but this could not be achieved due to the financial issues, caused by the global economic crisis. Because of other factors, such as contemporary British home affairs and research policy debates, the Hungarian department came into existence only a few years later and without Macartney. However, their professional relationship and friendship survived. ${ }^{14}$ Later in 1943, Szekfü - because of his anti-Nazi stance - was thinking about emigration to England through Turkey hoping that - with the help of Macartney - he might get a job as a professor in Oxford. Nothing came of this idea eventually, since the Hungarian Ministry of Foreign Affairs did not fund Szekfü's journey to Istanbul. ${ }^{15}$ There was also a question whether Macartney had the power at that time to help his fellow professor by granting him a position at a university. Anyhow, their professional relationship provably survived the storms of the war, since Macartney wrote a review about Szekfü's work Állam és Nemzet [State and Nation] in the English Historical Review of 1947. ${ }^{16}$

Between 1938 and 1946, Macartney worked as a public official in the service of the Foreign Office, first as an associate of the Foreign Research and Press Service (F.R.P.S.) - lead by Arnold Toynbee - then, from 1943, as the employee of the Foreign Office Research Department (F.O.R.D.). ${ }^{17}$ Since the 1930 's, the Foreign Office regularly consulted with him about Eastern European and Hungarian affairs which was a common procedure in its functioning, since they were keeping record of the temporarily inactive members of the diplomatic apparatus, using their expertise. As a Foreign Office man, one may call him graphomaniac, but according to the contemporary British laws all his longer writings had to 
be authorized by the Foreign Office. The works created as an official can be put in a well-defined thematic group. Between 1938 and 1946, he wrote nearly 120 shorter or longer memorandums about Eastern Europe and Hungary for the Foreign Office. As an employee of the F.O.R.D. between summer 1943 and autumn 1946 - he added side notes, of different lengths, to almost every diplomatic report in connection with Hungary (Minutes). This meant more than 300 Minutes in three years, all of these proving that Macartney had accurate and up-to-date information about Hungarian affairs. ${ }^{18}$ In the beginning of 1940, the leading officials of the Foreign Office discussed Macartney's work, visitation in Hungary and freshly made memorandum in a voluminous material. It is clear from the archive of the foreign affairs that Macartney has been indispensable by that time in Hungarian and Eastern European affairs, however, his actions were criticized by the British Foreign Office. ${ }^{19}$ In 18 November 1940, Macartney sent a letter from the All Souls College to the Foreign Office in which he analysed an earlier speech of István Csáky - Hungarian Foreign Minister - claiming that Hungary cannot openly commit itself on British friendship, but Budapest must be encouraged to draw closer to England. Philip B. Nichols - counsellor of the Foreign Office commented in the side notes, written to Macartney's opinion, that England cannot simply ignore the fact that Hungary joined the Tripartite Pact, and if Macartney prepared for a pro-Hungarian speech Nichols would want to see the manuscript beforehand, since he resented the handwriting of Macartney. ${ }^{20}$ On November 4, 1942 in a note addressed to Leo Amery, Macartney criticised the sharply anti-Hungarian Yugoslav broadcast of the BBC, but at the same time he mentioned that in the light of the Újvidék (Novi Sad) Massacre it is partly understandable. In his notes, he asked the foreign affairs to reduce the anti-Hungarian tone of the BBC. He personally did not want to have to do anything with it to avoid being accused of Hungarian-friendship and sympathy towards the Kállay government. Leo Amery, who served as a minister of India and Burma Affairs, forwarded the request to Anthony Eden the Minister of Foreign Affairs with the comment: „He himself is a good friend of both nationalities (i.e. Jugoslavs and Hungarians), though undoubtedly pretty proMagyar, and feels the danger to the future reconstruction of South Eastern Europe if mutual bitterness is allowed to go too far." ${ }^{21}$ The historian of the All Souls College played a decisive role in the Eastern European British plans of spring $1943^{22}$ which, at the end, was not successful. But the failure of this was not up to Macartney, since the Red 
Army occupied the area. As an employee of the Foreign Office Research Department and because of official request, he wrote a 34 pages long memorandum $^{23}$ - using typewriter - in November 1944 about the national minorities of Hungary. It is clearly visible from his writings that he had thorough historical knowledge about the ethnic situation in the Carpathian Basin. He combined this knowledge well with experiences gathered as an expert of minorities. He gave a similarly extensive and accurate analysis about the Soviet dominance experienced in Hungary in the summer of $1945 .^{24}$ From 1943, he edited the weekly press reviews of the Foreign Office (Reports \& Bulletins of Axis Controlled Europe) - in connection with the region - and later he played a major role in the composition of the Handbook about Hungary (1944-1945). ${ }^{25}$ Furthermore, he closely cooperated with important organisations of the British Foreign Office and Intelligence, such as the Political Intelligence Department (P.I.D.) and the Warfare Executive Committee (W.E.C.) during World War II. In this function of his, he was the one - although pro Hungarian - who interrogated Miklós Horthy - from British part - in July 17 and 18, 1945 while Horthy was a prisoner of war in Luxemburg. ${ }^{26}$

Macartney's career, as a historian and a professor, is mainly connected to the All Souls College in Oxford. Between 1936 and 1965, he was a Research Fellow and after 1976 until his death in 1978 a Fellow Emeritus. Between 1951 and 1957, he had classes at Edinburgh University (Montagu Burton Professor of International Relations). At the end of 1946, Macartney left the foreign affairs service and he dedicated all his time to his scholarly work. Most of his private library (826 items, 112 of which were in Hungarian including numerous works from Gyula Szekfü, dedicated to Macartney) can currently be found in the Lancaster University Library. ${ }^{27}$

C. A. Macartney's writings and Hungarian connections cannot be narrowed down to his publishing in connection with Hungarian history. Apart from his most well-known work (October Fifteenth. A History of Modern Hungary 1929-1945), he published dozens of monographs, essays and articles about Hungary. His collection of publications between 1915 and 1978 include 80 items, some of which gave Macartney international popularity. ${ }^{28}$

During his publishing and public life, Macartney held many lectures in connection with Hungary, by the request of the Royal Institute of International Affairs (Chatham House). ${ }^{29} \mathrm{He}$ had been in Hungary more than 20 times between 1921 and 1971 and from 1940, in the Foreign 
Office's administration, he was considered the number one expert on Hungary. Still, the British and Hungarian public opinion could know him better through BBC broadcasts until 1943. These appearances on the radio generated controversial effects and reactions, and after them Macartney was clearly treated as a pro-Hungarian Horthy regime supporter. ${ }^{30}$ This became the reason of political and personal breakup with Robert SetonWatson, who was considered a pro-Czech, pro-Serbian, and proRomanian. The relationship between the two "lobbyists of Eastern Europe" ended permanently when Macartney, in the early autumn of 1938, published two articles in the Times, in which he claimed that the Hungarian-Slovak hostility can be settled if the Great Powers fulfil Hungary's needs - which according to him were legitimate - in connection with the southern regions of Upper Hungary. ${ }^{31}$

A strange irony of their conflict-affected relationship is that it was Hugh Seton-Watson, son of Robert Seton-Watson, who wrote probably the fairest short biography about Macartney three years after his death. ${ }^{32}$

\section{Macartney's writings about Hungarians and the Hungarian history}

In the concluding historic work Hungary, published in 1934, and later in its edited and extended version (1962), and in the works Problems Of The Danube Basin and October $15^{\text {th }}$, Macartney did not only provide historical analysis but tried to depict the so-called Hungarian national character as well. His 376 pages long work Hungary - published in 1936 in Hungarian - starts with the statement that the region of the Carpathian Basin was constantly under attack, and the defence against these built in to the Hungarian national character. However, the inevitable and involuntary defence does not appear as a part of the decline depicted by Szekfü but it strengthens the survival skill of Hungary in a positive sense. Macartney dedicated almost a hundred pages to the schematic overview of the Hungarian history, from the foundation of the state until 1931, especially highlighting the 19th century, where the national fight was held against the Habsburgs and the issues of nationalities were linked to the defence of the Hungarian state's integrity. ${ }^{33}$ Further on, the volume describes the constitutional, institutional and socio-historical aspects of Hungary, with thematic overview and a serious critic. The author states that the country has no written constitution and, in practice, the power of 
the Holy Crown, as a law, is applicable through the institutions and administrative structures of the country. Macartney dedicated twenty pages to the overview of the Hungarian churches, emphasizing that there is no - and never has been - an Established Church but still, the churches, especially the catholic, have a special role because of its function in the education. The protestant churches, especially the Reformed Church, are described as a "Hungarian religion", mentioning Sárospatak as an example, which he visited in February $1946 .^{34}$ The author introduces the history-shaping power of the Hungarian aristocracy through the history of the Esterházy family, emphasizing that Hungary is one of the few countries around the world where the role of the aristocracy barely decreased. ${ }^{35}$ Macartneys's opinion regarding the Hungarian gentry's class was controversial and nuanced. According to the British historian, it is a positive aspect that this class identified itself with the Hungarian nation for a long time and they provided the main body the Hungarian national movement. However, in his opinion they were narrow-minded, their class was closed, they tried to get to a superior position above everyone else, and they were also the ones trying to take actions the most forcefully against the ethnic groups. A good indicator of the gentry's influence, according to the author, is the career of Miklós Horthy and Gyula Gömbös in the 1930s. The citizenship of Hungary is presented from the point of view of the urban development, the history of the merchant classes, and the introductions of the urban classes of German origin. Concerning the Jewish population of Hungary, Macartney examines the relationship of the Hungarian state and the Jews through the corresponding laws, but neither does he take a side in their role in the country's history nor does he evaluate the coexistence.

In connection with the introduction of Hungarian peasantry and working class, the description of the peasantry was longer (29 pages), emphasizing that Hungary is a rural country where the faith of the peasantry is inseparable from the aristocracy and nobility, even if it had never been in power throughout the history. During the introduction of the laws concerning the peasants and the peasant movements, the sympathy of the author is without doubt. The Land Act of 1920, the following land reform novella, the peasant party of István Szabó Nagyatádi, Gaszton Gál and Tibor Eckhardt, are all observed through this positive focus point. Similar methods of analysis appear in connection of the working class. The Hungarian working class, according to Macartney, is barely respected and young who always have to fight for their rights. He considered the 
Hungarian trade union movement, the Bethlen-Peyer pact $^{36}$ and the social security act a positive outcome, which was the reason of successful integration of the working class into the society by $1934 .^{37}$ In the 1920 s, Macartney, as an employee of the League of Nations, was said to be an expert of ethnic minority issues. No wonder he dedicated a whole chapter to this problem. After the listing and short historical overview of the ethnic groups of Hungary, (with a special focus on the Germans, mentioning - with a peculiar logic - the effects of the numerus clausus) the author emphasizes that the official policy towards ethnic groups barely differs from the one before 1914. In his opinion, the whole question is neuralgic because it links closely to Hungarian minorities living abroad and to the revisionist policy of Budapest. Additionally, any alteration in the borders can change the ethnic ratio of the region. This argument is further discussed in a separate chapter, about the problem of the revision, which is essentially a correct historical analysis, however the final conclusion is a bit naïve, since, according to Macartney, a western type national modernization can redefine the relationship of the state and nation in each country of the region and can bring border permeability. ${ }^{38}$ The review of the contemporary Hungarian foreign policy is also balanced and thorough, clearly showing that the author has diplomatic experience. The foreign affairs of Hungary after the Treaty of Trianon are analysed through the double objective of searching for an ally and breaking the isolation. The situation after 1933 is also mentioned which sheds light on the assumption that Budapest is fluctuating between Italy and Germany. Yet, the conclusion is similarly naïve, thinking that the German threat can bring the small countries of the Danube basin together, granting Hungary territorial concessions in this constellation. ${ }^{39}$ At the end of the volume, Macartney - as a flash-forward - depicts the hopeful future of Hungary from mainly economic historical point of view. This was also caused by the economic consolidation of the Bethlen government which he wrote about in a small separate article, published in Munich in the Egész Látóhatár, a Hungarian literature and political journal. ${ }^{40}$ The reason for the independent chapters in the Hungary about the form of government and the issues around the king might be found in the fact that Macartney was as serious expert, not only in Hungarian history, but in the early modern and modern Austrian as well. As a historian, it was logical that he was interested in the joint past and the turning points of the two nations. For this reason he dedicated 74 pages in his 908 pages long monograph of the Habsburg Empire published in 
1969 and edited in 1971 - to a comprehensive description about the Compromise. ${ }^{41}$ Nowadays, the volume is reprinted and it can be seen as the forerunner of the approach of emphasizing the history of empires over the national one, putting the central institutions of the Monarchy, the central apparatus of the state, the elite of the empire, the royal edicts and provisions and its consequences into the focus. ${ }^{42}$ Macartney emphasizes that he did not want to write national history, ${ }^{43}$ since that would definitely distort the image, but the part of Hungary in the empire was described in a separate chapter. ${ }^{44}$

In his opinion, by signing the Compromise ,the existence of the Habsburg Monarchy and the inclusion of Hungary within it, were vital to the very existence of Hungary, since without it the centrifugal forces would operate quite unchecked. Hungary must therefore support the Monarchy, and offer the Monarch such support as to make it worth his while to forgo what the centrifugal forces could offer. "45 However, he did not consider the Compromise a universal long lasting solution for the problems of the Monarchy and the region. It was more like an ad hoc agreement in the current situation between the court of Vienna and the Hungarian elite which the political leaders of other nationalities - having no better solution - accepted. ${ }^{46}$ In the opinion of Macartney, for the Hungarians in 1867 , in this respect, the national and ethnic minority issues (nationalism) were more important than any social, economic or foreign affair. Before jumping to the conclusion that Macartney only comments the Compromise in a summary in all his historical works in connection with Hungarians, two more aspects should be taken into consideration. First, Macartney was not only the expert of the Hungarian but the Austrian history as well (outstanding German skills, Austrian diplomatic service), knowing well the Austrian home policy at the time of the Compromise. Second, almost every - shorter or longer - work of him about Hungary, served an educational purpose because of which the language has been simplified by the request of the publisher.

In 1970, in a longer essay, Macartney summarized his standpoint in connection with the Compromise. ${ }^{47}$ First of all, he thought that the clarifications of the historical conceptions are essential, so he separated and defined the meaning of the Compromise and the dualism. He claimed that, until the Compromise was nothing more than a bilateral agreement, between the Hungarian king of Habsburg origin (Franz Joseph) and the representatives of the Hungarian nation (based on the 1867/12. article), the dualism - based on the above-mentioned law - meant a wider political 
system, determining the political structures of the Habsburg Monarchy up until 1918. The countries of the Hungarian Crown and the former Hereditary Lands had different structure and independent statehood, making them two political identities before the year 1867, but they always had common affairs. Macartney emphasises that the Pragmatica Sanctio had already contained these common affairs. ${ }^{48}$ In his opinion, the real question is whether the Compromise gave a real solution for the problem or is it only an attempt to answer. During his overview, detailed information is given about the direct background of the Compromise and the oppressive and unsustainable system of the neo-absolutism. In this respect, Macartney claimed that the beginning of the Risorgimento (i.e. the war with the Kingdom of Sardinia-Piedmont and the peace in Villafranca), the role of the German-Austrian opposition in the empire, and the actions of the Hungarian opposition are equally important. However, he emphasized that the latter two were divided into factions. The leading power of the Hungarian Opposition, the strengthening Deák party (in Macartney's words) from 1855, rejected the separatism, accepted the Pragmatica Sanctio, but according to Macartney even Deák thought that the preceding concessions about the common affairs are excessive. The 1859 defeat of the Austrian Army in Lombardy accelerated the rhythm of the agreement policy but in Macartney's opinion Franz Joseph did not connect this defeat to the "gesture policy" towards Hungarians, because his main goal was to keep the Monarchy together. ${ }^{49}$ The concessions made (October Diploma, February Patent) meant a constitutional reform mostly for the Austrian provinces. Still, the federal constitutional reform, led by the elite aristocracy of the empire, failed. In this respect, the actions and program of the Federal Noblemen's Party - led by the Czech count Jaroslav Clem-Martinitz - were total failures between 1859 and 1861. Furthermore, between 1861 and 1865 the Austrian-German wing, which represented a powerful program of centralisation, strengthened so much that the operation of the Imperial Diet was not only boycotted by the Hungarians but by the Czech, Croatians and Polish as well. According to Macartney, the only rift between the Hungarian and Austrian side by 1866 was that Franz Joseph only supported the idea of an imperial parliament. However, the basis for negotiation had already been there concerning the common affairs and the April Laws. ${ }^{50}$ Macartney, on the other hand, emphasizes that it was not Deák and his party who wrecked the federalist ideas of the Polish, Czech 
and Croatian political leaders, but the deep and diverse mutual conflicts between the Slav elite of the empire. ${ }^{51}$

The historian described Count Gyula Andrássy's important role in the creation of the Compromise. The count, as a Hungarian aristocrat with property in Upper Hungary and with liberal principles, suggested the Hungarian-Austrian (German) cooperation against the Slavic danger. This - summarized by the British historian - could be the foundation of the dualist system. ${ }^{52}$ He claimed, with a peculiar parallel, that in the Austrian home policy, the federalists and the centralists of the empire were both attacking the pro-Compromise Habsburg court, such as the Kossuth party attacked Deák in Hungary, even using the same reasons: we are forced to make too many compromises. ${ }^{53}$

His work, October Fifteenth. A History of Modern Hungary 1929-1945, was published in 1956 in two volumes - in Hungarian only in 2006 - and appeared as a university textbook for decades in the British and American higher education. In this 519-page-long work, the author reveals the history of the Horthy regime in unprecedented depth and with thoroughness through his diplomatic and personal experiences, in a way that has never occurred in British literature. ${ }^{54}$ In the creation of the volume, the author was not only helped by experiences like diplomatic service for the Foreign Office, but also by his travels to Hungary and by his continuous and continuously maintained connections with part of the intellectual and political elite of the Horthy regime. After 1945, Macartney was in continuous relationship with the "official" historians of Hungary apart from those who emigrated. However, his political stance can only be observed in the help provided to Hungarians arriving to England after the repression of the revolution of 1956. The author expresses his criticism multiple times about the Horthy regime in the sketched tableau, from the background of Trianon until the fall of the Szálasi period. Although the volume concentrates more on the introduction of the general home policy of the time, Macartney does not avoid showing the contemporary Hungarian economy, society and connections of the social classes to the world of politics. In this matter, he rightfully emphasizes (coherently integrated with the strong social skills experienced in his historical point of view) that the political representation of the poor and politically oppressed worker-peasant classes decreased (mostly because of the reduction of the suffrage and the creation of the unified governing partyEgységes Párt) to the minimum and became marginal during the consolidation of Bethlen. ${ }^{55}$ By looking at the foreign affairs of the 1920s, 
Macartney considers the anti-bolshevism and anti-communism of the system and the revisionist goals equally important, while emphasizing that this anti-communism and anti-bolshevism of the contemporary Hungarian elite laid on a socially widespread consensus caused by the failure of revolutions in 1918-19. Coming along this way, Macartney, using some criticism, emphasizes that there was no real alternative to the German orientation in the Danube Basin, not even in the first year of the Gömbös government, since the Italian-Austrian-Hungarian approach could not counteract it. ${ }^{56}$ Macartney undoubtedly had sympathy for Miklós Horthy. He highly valued his temperate conservatism, his uprightness, but most likely the fact that - in his opinion - the Hungarian governor never insisted categorically on taking and keeping the political power, he was persuaded by his surroundings. ${ }^{57}$

\section{Summary and Outlook}

Macartney was received - as a member - into the Hungarian Academy of Sciences after the war. He proudly used this title until his death, even though he had been deprived of the title due to communist pressure in 1949. In 1946, he retired from Foreign Office service but kept on the active relationship with Hungarians. He visited Hungarian organisations in the USA multiple times and travelled to Austria after the repression of the revolution of 1956 to help Hungarians in refugee camps. As a leader of the Anglo-Hungarian Society before the war and later and as the president of the Anglo-Hungarian Fellowship, he had a great role in making the integration of the Hungarian refugees in England successful. Neither his personality, nor his works and actions were uncontroversial. This can be found mostly in his relationship with Robert Seton-Watson, who always considered Macartney slightly anti-Semitic and largely proHungarian. However, Macartney, at one of his last conferences (Haifa, April 1972), proved him to be wrong in his lecture about Hungarian foreign affairs and the Jewish question, which lecture was followed by steady appreciation. ${ }^{58}$

The historian-diplomat Macartney undoubtedly made a great effort to make the Horthy regime nuanced and less hostile in the eye of the British public opinion. This was achieved mostly by his service in the Foreign Office and the radio speeches. He aimed to be objective, professional and accurate in his historical writings (like in the introduction and evaluation 
of the Compromise). The sympathy towards Hungarians appears in many of his other works. The professor of history of the All Souls College kept up his connections with Hungary but, by this time, these were mostly professional rather than political ones.

Notes

1 The paper is the edited and extended version of a presentation from the conference, Diplomat writers-writer diplomats held by the Department of Netherlandish Studies at the University of Debrecen. The necessary research for the paper was made with the support of the Relationships of the Hungarian aristocracy in the $16-20^{\text {th, }}$ NKFI K 120197 tender, and within the framework of the Kuno Klebersberg Research Scholarship (September-October, 2016).

2 Macartney, October Fifteenth; Macartney, The Habsburg Empire 1790-1918.

3 Evans, 'The Making of October Fifteenth: C.A. Macartney and his Correspondents', 259-271. Seton-Watson, 'Carlile Aylmer Macartney 1895-1978', 411-432. Beretczky, Scotus Viator és Macartney Elemér: Magyarország-kép változó előjelekkel (19051945); Lojkó, 'C.A. Macartney and Central Europe'; Czigány, 'Trianon angol kritikusa. Száz éve született „Macartney Elemér”; László, “The Political Conflict between R. W. Seton-Watson and C.A. Macartney over Hungary', 167-193; Ránki, 'Találkozásaim Macartney Elemérrel'.

4 The British and Hungarian public opinion could meet the Hungarian version Macartney's name in the Hungarian BBC broadcasts. In depth about him on the radio: Pál, ‘„Jó estét kívánok, itt Macartney Elemér beszél”. C.A. Macartney és a BBC magyar adása', 340-357.

5 Macartney, Studies on Early Hungarian and Pontic History. Varirorum collected studies. The volume contains 17 papers of Macartney about the Early and Late Middle Age Hungary, as well as the obituary of Seton-Watson and a 7 pages long chronological list of Macartney's works from 1915, selected by the editors.

6 Szekfü Gyula (1883-1955) a Hungarian historian and leading ideologist of the Horthy regime. From 1945 to 1948, he was the Hungarian ambassador to Moscow. His main work: Három nemzedék (Three Generations). 1920.

7 See also: Correspondence of József Balogh and C.A. Macartney. National Széchenyi Library Manuscripts, 1/2064., and Dénes, A történelmi Magyarország eszménye. Szekfü Gyula a történetiró és ideológus, 364. 450.

8 This is when his controversial relationship with Robert Seton-Watson started. See also: Correspondence with C.A. Macartney. The file contains 15 letters from the period between 1921 and 1938, 14 of which were written by Macartney to SetonWatson. More about the letters: Lojkó,'C.A. Macartney and Central Europe', 44.

9 About the contemporary British connections of Sándor Krisztics and the Hungarian National Association: Barta, 'Oxfordi Magyar Liga a Magyar Önrendelkezésért', 371.

10 Macartney, October Fifteenth. „To the honoured memory of Iván Hindy, General. † August $26^{\text {th }}$ 1946." 
11 Fanshave \& Macartney, What the League Has Done 1920-1936; League of Nations Union. (LNU) 195. March 1936. 94.; LNU Miscellaneous. 1. Austria. What the League Has Done for Austria. 1934. LNU Pamphlet (with the contribution of C. A. Macartney); LNU Miscellaneous. 2. The League and Human Welfare. March, 1939. LNU Pamphlet, 155. Rochester, (Chapter 4 - The Relief of Refugees - with the contribution of C.A. Macartney. 60-81); LNU Miscellaneous. 2. Five Years Treaties 1919-1923. LNU Pamphlet, 156. London, September, 1924. (with the contribution of C. A. Macartney 12.); LNU Miscellaneous. 2. The International Federation of League of Nations Societies. LNU Pamphlet, London, April, 1933. (with the contribution of C. A. Macartney 20.); LNU Miscellaneous. 3. The Union at Work. LNU Pamphlet, 252. London, July, 1923. (with the contribution of C. A. Macartney); LNU Miscellaneous. 4. The League Cares for the Homeless. LNU Pamphlet, London, 1928. (with the contribution of C. A. Macartney); LNU Miscellaneous. 4., Minorities by C. A. Macartney. LNU Pamphlet, 268. London, January, 1929. (C. A. Macartney's 40-page-long paper mentions Hungary and Hungarians 11 times: 8., 10. 17., 18., 25-29., 31., 37.); LNU Miscellaneous. 4. A Memorandum on the Protection of Minorities. London, 1934. (30-page-long recommendation for the British government, with the contribution of C. A. Macartney); LNU Miscellaneous. 6. Treaty Revision and the Covenant of the League of Nations. LNU Pamphlet, 353. London, August, 1933. (with the contribution of C. A. Macartney. Hungarian references: 9-13.); LNU Miscellaneous. 7. The Assembly at a Glance. LNU Pamphlet, 373. London, October, 1934. (with the contribution of C. A. Macartney. Hungarian references: 10-11.); LNU Miscellaneous. 7. The League of Nations and the Coal Problem by C.A. Macartney. LNU, Pamphlet, 384. London, May, 1935. 29.; LNU Miscellaneous. 8. Refugees and the League. LNU Pamphlet, 389. London, September, 1935. 60. (using C. A. Macartney's Refugees); LNU Miscellaneous. 8. The Minorities Problem. Report by the Executive Committee of the League of Nations Union. LNU Pamphlet, 427. London, June, 1942. 8. (with the contribution of C. A. Macartney. Hungarian references: 2-3.); LNU Miscellaneous. 10. Social and Economic Planning by C. A. Macartney. Report on the Industrial Advisory Committee Conference (February 19-21, 1935.). LNU Pamphlet, 383. London, May, 1935. 95. (C. A. Macartney's prologue).

12 Macartney, Hungary; Macartney, National States and National Minorities.

13 Partly because of Szekfü's encouragement, Macartney contributed actively to the publishing of the sources of the early Hungarian history in English, between 1938 and 1951: Studies of the Earliest Hungarian Historical Sources. 1-2.: The Lives of St Gerald, The Composition of the Zágráb and Várad Chronicles and their relationship to the longer narrative chronicle., Studies of the Early Hungarian Historical Sources III/1-2. The relations between the narrative Chronicles and other historical texts, The Attila Saga, The Hun Chronicle, and T., Studies of the Early Hungarian Historical Sources III-IV. (recte part IV.): The Hungarian Texts Relating to the life of St. Stephen. IV (recte part V): The interpretation of the Chronicon Posoniense and the Genealogy of Almus on (!) the Chronicon Budense, Studies of the Earliest Hungarian 
Historical Sources VI: Unrecognised components of the Chronicon Budense. VII: The Origin, Structure and the Meaning of the Hun Chronicle.

14 Czigány, 'Trianon angol kritikusa. Száz éve született „Macartney Elemér', 14.

15 Dénes, A történelmi Magyarország eszménye. Szekfü Gyula a történetró és ideológus, 364.

16 Macartney, 'État et nation by J. Szekfü', 264-265.

17 On the Foreign Research and Press Service (F.R.P.S.) and the Foreign Office Research Department (F.O.R.D.) more details: Bán, Pax Britannica. Brit külügyi iratok a második világháború utáni Kelet-Közép Európáról, 1942-1943; Brewin, 'Arnold Toynbee and Chatham House', 137-161 (C. A. Macartney mentioned: 132. 136. notes: 147., 212., 234., 248.). Keyserlingk, 'Arnold Toynbee's Foreign Research and Press Service, 1939-43 and its Post-War Plans for South-East Europe’, 539-558. (C. A. Macartney mentioned: 553: 21. and 71. notes)

18 The files dealing with Hungary and the Hungarian foreign affairs between 1938 and 1946 (FO/371/2300-5900) in The National Archives (TNA) of London/Kew contain 355 archive documents in which memorandums and minutes by Macartney - written by or contributed to - can be found. Apart from that the collection of the Bodleian Library Western Manuscripts of Oxford (Weston Library) contains the copies of Macartney's memorandum and private letters made for the Foreign Office (Carlile Aylmer Macartney Papers, MSS, Eng. Box 12.)

19 Activities of Mr. Macartney. TNA FO/371/24429/ 316-430.

20 Mr. C.A. Macartney to Mr. Nichols. Speech by Count Czaky (sic!) on Hungary's dependence upon the Axis. TNA FO/371/24431. C 12800/12482/21.

21 Jugoslav-Hungarian relations. TNA FO/371/5243. C 11783/5243/21.

22 Confederation in Eastern Europe. TNA FO/371/35261. U 716/58/72, U/723/58/72, U/2011/58/72, U/2079/58/72.

23 The Minorities of Hungary. TNA FO/371/39289. C 16272/21.

24 Political Situation: Soviet Domination of Hungary. Foreign Office Minute Macartney. 29 August 1945. TNA FO/371/48467. R 15313/26/21. 75-76.

25 Hungary Basic Handbook. London. Part I.: Historical, Political and Social. March, 1944., 99. Part II.: Economic Survey. May, 1944., 56. Part III.: Supplement. Who's Who. January, 1945., 108 (Chapter II. and V. of the $1^{\text {st }}$ volume, with the contribution of C.A. Macartney).

26 Report on Admiral Horthy. TNA War Office WO204/12489. In Hungarian: Egy angol professzor beszélgetései Horthy Miklóssal, 1128-1130, 1160-1162.

27 St Germain, The C.A. Macartney Collection.

28 Macartney, National States and National Minorities; Macartney, Hungary and Her Successors (1919-1937). The Treaty of Trianon and its Consequences. Macartney, The Danubian Basin. Macartney \& Palmer, Independent Eastern Europe.

29 Macartney had six lectures in the Chatham House (Royal Insitute of International Affairs-RIIA) between 1931 and 1946. The topics were mostly travel reports of Hungary. For more details: Macartney, The Situation in Hungary. October 12th 1931, Some Aspects of Present-Day Hungary. 2nd December 1937, Conditions in Hungary. 1946, March, 18, 1946, Ruthenia: A Problem of the Future. 27, February 
1936, Political Relations in the Balkans. 2nd February 1931, Hungary and the Present Crisis. 2nd February 1931.

30 Propaganda to Hungary. TNA FO/371/30965 C.5358.; Czechoslovak criticism of the BBC propaganda broadcast to Hungary. TNA FO/371/30965 C.6701/116/21.; BBC Surveys of European Audiences: Czechoslovakia, Poland and Hungary. TNA FO/371/34383 C. 3345/50/62.; Hungarian Broadcast from London. TNA FO/371/26624 C. 4270/2240/21.; Hungarian Broadcast from BBC. TNA FO/371/26624 C. 5898/2240/21.; Jaroslav Císar̆ notes for Seton-Watson on the radio broadcast of Macartney (2-page-long typed text, no date, probably OctoberNovember 1941). UCL-SSSEES, Seton-Watson Papers, SEW 14/1/1.

31 Grievances of Minorities: The Case of Hungary. A letter by C. A. Macartney, The Times, 1938. Oct. 7, 10; Letter of C. A. Macartney, 19 September 1938. The letter was only published by The Times after the signing of the Munich Agreement, due to political pressure. Carlile Aylmer Macartney, Magyar and Slovak. The rival claims: an opportunity for just revision, The Times, 1938. oct. 26, 5-16.

32 Seton\&Watson, Carlile Aylmer Macartney 1895-1978.

33 Macartney, Hungary. The Magyars in History, 35-126.

34 Macartney, Hungary, 155. Macartney was in Hungary between January 22 and February 12, 1946 (Budapest and Sárospatak). See more: Organizations in Liberated Hungary. Ministry of Information-Related papers. TNA FO 930/262.

35 Macartney, Hungary, 147.

36 The Bethlen-Peyer Pact signed in December, 1921 was a political agreement between the right wing Prime Minister Count István Bethlen and the leader of the Hungarian Social Democrats, Károly Peyer.

37 Macartney, Hungary, 223-270.

38 Macartney, Hungary, 332.

39 Macartney, Hungary, 352.

40 Macartney, 'A bethleni konszolidáció', 33-36.

41 Macartney, The Habsburg Empire 1790-1918, 495-568. Chapter 11: Eight Years of Correction.

42 The impact of Macartney's historical views in connection with the Habsburg Empire can be found in Robert J. W. Evans's and Péter László's works, who was the student of the professor of the All Souls College, University of Oxford. See: Evans, The Making of the Habsburg Monarchy, 1550-1700: An Interpretation; Péter, Az Elbától keletre. Tanulmányok a magyar és kelet-európai történelemböl.

43 Macartney, The Habsburg Empire 1790-1918. xii.: „But the tribal histories [...] cannot be completely satisfactory even for their own tribes, for the political, social and economic development of each people was bound up with and largely conditioned by that of the others, without some knowledge of which it does not even make a sense."

44 Macartney, The Habsburg Empire 1790-1918, 687-739. Hungary under Dualism, 1867-1903.

45 Macartney, October Fifteenth, 11. 
46 Macartney, The Habsburg Empire 1790-1918, 567.: „The Compromise was not even in intention a general settlement of the problem of the Monarchy, still less of that of Central Europe. It was an ad hoc agreement between Francis Joseph and the Hungarian leaders, other parties intervening with more or less effects, under which each "compromised" by making certain sacrifices of rights and aspirations in the interest of security."

47 Macartney, 'The Compromise of 1867', 287-300.

48 Macartney, 'The Compromise of 1867', 288.: Pragmatic subjects, common interests.

49 Macartney, 'The Compromise of 1867', 291.: „After this there began the story of Franz Joseph's retreat towards constitutionalism, his object being to find an ally which would help him to hold the Monarchy together at the least cost of his authority. It was zigzag course, during which one such ally after another was tried and proved ineffective. It is often written [...] that this concessions to Hungary began on the morrow of the armistice of Villa Franca. This is not the case [...] Francis Joseph was still entirely against any concessions to any group of Hungarians."

50 Macartney, 'The Compromise of 1867', 295.

51 Macartney, 'The Compromise of 1867', 296.

52 Macartney, 'The Compromise of 1867', 296.: „You take care of your Slavs [...] and we take care of ours /the version barbarians - for the Slavs -is not authenticated, although it would have been characteristic enough/ a lapidary formulation of what is usually said to have been the philosophic basis of Dualism."

53 Macartney, 'The Compromise of 1867', 296-297.: „, [...] in Hungary [...] a considerable party still thought that Deák was going too far in conciliation, and even more in Austria, from the federalists headed by Belcredi, on the one hand and the German centralists on the other."

54 In details about the circumstances of writing the volume, see: Evans, 'The Making of October Fifteenth.' C.A. Macartney and his Correspondents', 259-271.

55 „The political subjugation of the dispossessed agrarian classes, threequarters accomplished when the new franchise was introduced, was soon completed, those few deputies of genuine small peasants or labourer origin as had survived the Party fusion being, with a handful of exceptions, digested and quietly excerted by the simple process of dropping them all of the list of Party candidates." Macartney, October Fifteenth, 1: 66.

56 „It is important for the understanding of Danubian politics of the day to be clear that neither Gömbös, nor for that matter many of the Austrians who followed it through that an Italian orientation, even if it involved temporary renunciation of the Anschluss or even opposition to it, really constituted an anti-German policy." Macartney, October Fifteenth, 1:138.

57 „He was upright, honourable and courteous, generous, open-hearted and affecttionate...Nor, in the writer's opinion, is there any real foundation for the accusations brought against him of ambition and vanity. He had not elbowed or intrigued his way towards power; it was pressed on him by others, who assured him that it was his duty to accept it, as being the fittest man for it." Macartney, October Fifteenth, 1:52-53. 
58 Macartney, 'Hungarian Foreign Policy during the Inter-War Period, with Special Reference to the Jewish Question', 125-136. See also: Major, 'Macartney a magyar zsidókról'.

\section{Bibliography}

Barta, R. 1994. 'Oxfordi Magyar Liga a Magyar Önrendelkezésért.' [Oxford Hungarian League for Hungarian Self-Determination] Debreceni Szemle 1994/3: 370-376.

Bán, D.A. 1996. Pax Britannica. Brit külügyi iratok a második világháború utáni Kelet-Közép Európáról, 1942-1943. [Pax Britannica. British Foreign Office Papers on the post WWII East Central Europe, 1942-1943]. Budapest: Osiris.

Beretczky, Á. 2005. Scotus Viator és Macartney Elemér: Magyarországkép változó elöjelekkel (1905-1945). [Scotus Viator and Mcartney Elemér: Hungary's Image with Various Signs (1905-1945]. Budapest: Akadémiai.

Brewin, C. 1994. 'Arnold Toynbee and Chatham House.' Bosco, A. \& Navari, C. (eds.) Chatham House and British Foreign Policy 19191945. The Royal Institute of International Affairs during the interwar period. London: Lothian Foundation Press.

Czigány, L. 1995. 'Trianon angol kritikusa. Száz éve született „Macartney Elemér." [The English Critic of Trianon. 100 ${ }^{\text {th }}$ Anniversary of Macartney Elemér's Birth]. Magyar Nemzet. 1995. 1.19: 14.

Dénes, I.Z. 2015. A történelmi Magyarország eszménye. Szekfü Gyula a történetró és ideológus. [The Idea of Historical Hungary. Szekfü Gyula the Historian and the Ideologist]. Pozsony: Kalligram.

Egy angol professzor beszélgetései Horthy Miklóssal. 1993. [An English Professor's Conversations with Miklós Horthy] Élet és Tudomány. 1993/36:1128-1130.; 1993/37: 1160-1162.

Evans, R.J.W. 1979. The Making of the Habsburg Monarchy, 1550-1700: An Interpretation. Oxford: Clarendon Press.

Evans, R.J.W. 2004. 'The Making of October Fifteenth: C.A. Macartney and his Correspondents.' Péter, L. \& Rady, M. (ed.) British-Hungarian Relations since 1848. SSEES Ocassional Papers 62. London: University College. 259-271. 
Hungary Basic Handbook.1944. London. Part I.: Historical, Political and Social. March, 1944.; Part II.: Economic Survey. May, 1944.; Part III.: Supplement. Who's Who. January, 1945. (Chapter II. and V. of the $1^{\text {st }}$ volume, with the contribution of C.A. Macartney).

Keyserlingk, R.H. 1986. 'Arnold Toynbee's Foreign Research and Press Service, 1939-43 and its Post-War Plans for South-East Europe.' Journal of Contemporary History. 21: 539-558. https://doi.org/10.1177/002200948602100403

László, P. 2004. The Political Conflict between R. W. Seton-Watson and C.A. Macartney over Hungary. Péter, L. \& Rady, M. (ed.) BritishHungarian Relations since 1848. SSEES Ocassional Papers 62. London:University College.167-193.

Lojkó, M. 1999. 'C.A. Macartney and Central Europe.' European Review of History. 6/1. https://doi.org/10.1080/13507489908568220

Macartney, C.A. 1934. Hungary. The Modern World. A Survey of Historical Forces. Foreword by H.A.L. Fischer. London: Ernest Benn Ltd. Hungarian edition: Macartney, C.A. 1936. Magyarország. Budapest: Révai Világkönyvtár.

Macartney, C.A. 1934. National States and National Minorities. Issued under the auspices of Royal Institute of International Affairs. London: Oxford University Press.

Macartney, C.A. 1937. Hungary and Her Successors (1919-1937). The Treaty of Trianon and its Consequences. Oxford: Oxford University Press.

Macartney, C.A. 1938. 'The Lives of St Gerald, The Composition of the Zágráb and Várad Chronicles and their relationship to the longer narrative chronicles.' Studies of the Earliest Hungarian Historical Sources. 1-2. Études sur l'Europa Centre-Orientale. Ostmitteleuropäische Bibliothek 18. Dirigées par Emeric Lukinich. 456-507.

Macartney, C.A. 1938. 'Grievances of Minorities: The Case of Hungary. A letter by C.A. Macartney.' The Times. 1938. Oct. 7.: 10.

Macartney, C.A. 1938. 'Carlile Aylmer Macartney, Magyar and Slovak. The rival claims: an opportunity for just revision.' The Times. 1938. oct. 26. 5-16.

Macartney, C.A. 1939. The Danubian Basin. Oxford Pamphlets of World Affairs. 10. Oxford: Oxford at the Clarendon Press. New edition: 1941. Hungarian edition: Macartney, C.A. 1943. A Dunamedence problémái. 
[Problems of the Danube Basin] Cambridge.1942. Barker, E.(ed.) Current Problems 12. Budapest: Keresztes.

Macartney, C.A. 1940. 'The Hungarian Texts Relating to the life of St.

Stephen.' IV (recte part V) Studies of the Early Hungarian Historical Sources III-IV. (recte part IV.) The interpretation of the Chronicon Posoniense and the Genealogy of Almus on (!) the Chronicon Budense. Études sur l'Europa Centre-Orientale, Ostmitteleuropäische Bibliothek, 21/a, Dirigées par Emeric Lukinich.

Macartney, C.A. 1940. 'The relations between the narrative Chronicles and other historical texts. The Attila Saga, The Hun Chronicle, and T.' Studies of the Early Hungarian Historical Sources III/1-2. Etudes sur l'Europa Centre-Orientale. Ostmitteleuropäische Bibliothek 21. Dirigées par Emeric Lukinich.

Macartney, C.A. 1947. 'État et nation by J. Szekfü.' English Historical Review, 1947, 62/243: 264-265.

Macartney, C.A. 1951.'Unrecognised components of the Chronicon Budense. VII: The Origin, Structure and the Meaning of the Hun Chronicle.' Studies of the Earliest Hungarian Historical Sources VI. Oxford: Oxford University Press.

Macartney, C.A. 1952. A bethleni konszolidáció. [The Consolidation of the Bethlen Era] Egész Látóhatár. Irodalmi és politikai folyóirat. 3.2: 33-36.

Macartney, C.A. 1956-1957. October Fifteenth. A History of Modern Hungary 1929-1945. I-II. Edinburgh: Edinburgh at the University Press. Hungarian edition: Macartney, C.A. 2006. Október tizenötödike. A modern Magyarország története 1929-1945. I-II. Budapest: Gede testvérek.

Macartney, C.A. 1969. The Habsburg Empire 1790-1918. London: Faber Finds. Reprinted with Correction 1971.

Macartney, C.A.\& Palmer, A.W. 1969. Independent Eastern Europe. London: Macmillan.

Macartney, C.A. 1970. 'The Compromise of 1867' Hatton, R. \& Anderson, M.S. (eds.) Studies in Diplomatic History. Essays in Memory of David Boyne Horn. London: Longman.

Macartney, C.A. 1974. 'Hungarian Foreign Policy during the Inter-War Period, with Special Reference to the Jewish Question.' Vago, B. \& 
Mosse, G.L. (eds.) Jews and non-Jews in Eastern Europe 1918-1945. New York/Jerusalem: Keter Publishing House.

Macartney, C.A. 1999. Studies on Early Hungarian and Pontic History. Varirorum collected studies. Czigány, L. \& László, P. (eds.) Aldershot: Ashgate Variorum.

Macartney, C.A. 2009. Hungary. From Ninth Century Origins to the 1956 Uprising. New Brunswick/London: Aldine Transactions. A Division of Transaction Publishers. The volume is the reprint of the 1962 edition.

Major, R. 1961. 'Macartney a magyar zsidókról.' [Macartney's Standpoint on the Hungarian Jews] Látóhatár füzetek. Munich.

Pál, M. 2004. '„J́ estét kívánok, itt Macartney Elemér beszél.” C.A. Macartney és a BBC magyar adása.' [“Good Evening! Here is Macartney Elemér Speaking." C.A. Macartney and the Hungarian Broadcast of the BBC]. Frank Tibor (ed.) Angliától Nagy-Britanniáig. Magyar kutatók tanulmányai a brit történelemröl. [From England to Great Britain. Hungarian Historical Studies on British History]. Budapest: Gondolat.

Péter, L. 1998. Az Elbától keletre. Tanulmányok a magyar és kelet-európai történelemböl. [East of Elbe. Studies from Hungarian and East European History]. Osiris: Budapest.

Ránki, Gy. 1978. 'Találkozásaim Macartney Elemérrel.' [ My Meetings with Macartney Elemér]. Élet és Irodalom, 1978. 7/8: 6.

Seton-Watson, H. 1981. Carlile Aylmer Macartney 1895-1978. Proceedings of The British Academy. LXVII. London: Oxford University Press.

St Germain, M.S. 1981. The C. A. Macartney Collection. Lancaster: Lancaster University Press.

\section{Archival sources}

Bodleian Library, Oxford, Carlile Aylmer Macartney Papers. Western Manuscripts, Weston Library, MSS, Eng. Box 12.

Széchenyi National Library, Budapest. Correspondence of József Balogh and C.A. Macartney. Manuscripts, 1/2064. 
Library of the School of Slavonic and South East European Studies, University College, London (UCL-SSSEES). Correspondence with C.A. Macartney. Seton-Watson Papers. SEW 17/15/5.

The National Archives (TNA), London-Kew, Hungary between 1938 and 1946. Foreign policy files. Foreign Office files, FO/371/2300-5900.

The British Library (BL) London, League of Nations Union (LNU). LNU Leaflets, Miscellaneous, Pamphlets. Vol. 1-10. 1923-1942.

Library of Royal Institute of International Affairs (RIIA) London, Macartney, C.A. 1931. The Situation in Hungary. October 12th 1931. The 25-page-long typed version of Macartney's lecture and the following debate.. 8/161.

RIIA Macartney, C.A. 1931. Political Relations in the Balkans. 2nd February 1931. The 24-page-long typed version of Macartney's lecture and the following debate. 8/120.

RIIA Macartney, C.A. 1931. Hungary and the Present Crisis. 2nd February 1931. The 24-page-long typed version of Macartney's lecture and the following debate. 8/551.

RIIA Macartney, C.A. 1936. Ruthenia: A Problem of the Future. 27, February 1936. 16-page-long version of Macartney's lecture and 11-pagelong typed version of the following debate. 8/399.

RIIA Macartney, C.A. 1937. Some Aspects of Present-Day Hungary. 2nd December 1937. 18-page-long version of Macartney's lecture and 12page-long typed version of the following debate. 8/475.

RIIA Macartney, C.A. 1946. Conditions in Hungary. 1946, March, 18, 1946. The 10-page-long typed version of Macartney's lecture and the following debate. 8/1209. 